\title{
Apoptotic Effect of Homobrassinin and Thiazino[6,5-b]indol is Associated with Downregulation of Heat Shock Proteins in Human Ovarian Adenocarcinoma Cells
}

\author{
Zuzana Solárová, ${ }^{1}$ Martin Kello ${ }^{1}$ and Peter Solár ${ }^{2, *}$ \\ ${ }^{1}$ Institute of Pharmacology, Faculty of Medicine, P. J. Šafárik University in Košice, SK-04154 Košice, Slovak Republic \\ ${ }^{2}$ Institute of Medical Biology, Faculty of Medicine, P. J. Šafárik University in Košice, \\ SK-04154 Košice, Slovak Republic \\ *Corresponding author: E-mail: peter.solar@upjs.sk
}

Received: 09-04-2020

\begin{abstract}
Phytoalexins are substances with antimicrobial properties produced by plants after being attacked by microorganisms, especially phytopathogenic fungi and viruses. They are also currently being studied for their antitumor effect. We aimed to study the apoptosis-stimulating effect of homobrassinin and thiazino[6,5-b]indol in human ovarian adenocarcinoma A2780 and A2780cis cells via flow cytometric analysis of annexin V/PI, caspase 3 and 9 activity, cytochrome C release, and smac-diablo accumulation. Using the western blot technique, we also monitored the effect of both indoles on the response of heat shock proteins in these cells. Thiazino[6,5-b]indol showed more pronounced sensitizing and/or pro-apoptotic effect compared to homobrassinin accompanied by increased smac-diablo accumulation at earlier time intervals and pronounced externalization of phosphatidylserine at $72 \mathrm{~h}$ in A2780cis compared to A2780 cells. The apoptosis stimulating effect of thiazino[6,5-b]indol in A2780cis cells was associated with significant irreversible downregulation of HSP70 and HSP90 and partly with a decrease of HSP40. On the other hand, cisplatin-induced the apoptosis of sensitive A2780 cells with reversible downregulation of HSP40 and HSP57. In conclusion, the effect of thiazino[6,5-b]indol on resistant A2780cis cells could have a great utility in both the potential prevention and the treatment of other cisplatin-resistant tumor cells.
\end{abstract}

Keywords: Homobrassinin; thiazino[6,5-b]indol; cisplatin resistance; apoptosis; heat shock proteins; human ovarian adenocarcinoma cells

\section{Introduction}

Ovarian cancer has the highest mortality rate of all gynecologic neoplasms among women in Western Europe and the United States. Women who have one first-degree relative with ovarian cancer have an increased risk (5\%) of developing ovarian cancer even without known genetic mutation (the average woman's lifetime risk is $1.4 \%) .{ }^{1}$ For most women, the standard of care remains surgery and platinum-based cytotoxic chemotherapy. Platinum-based drugs are the most active and effective treatment option for most patients with early-stage disease. Women with advanced disease will develop many episodes of recurrent disease with progressively shorter disease-free intervals. Eventually, the tumor is declared platinum resistant. Although paclitaxel chemotherapy has improved over the last two decades, the progression to free survival has remained fairly constant at about 18 months. Significant advances in the treatment over the last decade led to a significant prolongation of 5-year survival while the incidence of the disease has remained constant. ${ }^{2}$

Platinum resistance can occur in almost all patients with recurrent ovarian cancer. However, many patients with "platinum-resistant" disease respond to further platinum-based treatment. Platinum, either cisplatin or carboplatin, is given weekly with the addition of etoposide or paclitaxel. $^{3}$ or in combination with gemcitabine for two out of three weeks. ${ }^{4}$ Paclitaxel is one of the most active nonplatinum drugs used in this setting. Progression to free survival and overall survival increases significantly with paclitaxel administered weekly. ${ }^{5}$ In women with platinum-resistant ovarian cancer, antiangiogenic agents, like 
bevacizumab, may also play an important role. Indeed, these agents have been used as a monotherapy or in combination with low dose cyclophosphamide. ${ }^{6}$ Other drugs, such as aflibercept (VEGF trap), have been found effective in controlling ascites. ${ }^{7}$

Other than anticancer chemotherapeutics, synthetic analogs of several natural substances with antitumor effects, such as indole phytoalexins, were also tested at our institute. Phytoalexins are substances with antimicrobial properties produced by plants after being attacked by microorganisms, especially phytopathogenic fungi and viruses. We tested indole phytoalexins on both cisplatin-sensitive human ovarian adenocarcinoma cell line A2780 (parental) as well as its cisplatin-resistant derivative A2780cis and compared their response to indoles to determine the rate of the resistance of A2780cis cells. Surprisingly, we found that A2780cis cells are only 3.2 times more resistant to thiazino[6,5-b]indol (K157) compared to the parental cell line, as opposed to cisplatin, where A2780cis cells revealed 18 times lower sensitivity. ${ }^{8}$ Thus, the fold resistance of A2780cis cells compared to parental ones was surprisingly low, suggesting that A2780cis cells have much lower resistance to $\mathrm{K} 157$ than to cisplatin.

In the current work, we aimed to study the sensitizing effect of two indoles, homobrassinin (K1) and K157, on parental A2780 and cisplatin-resistant A2780cis cells. In addition to the apoptosis-stimulating effect of indoles, we were also interested in their effect on the response of selected heat shock proteins in these cells.

\section{Experimental}

\section{1. Cell Culture and Treatment}

Human ovarian adenocarcinoma cell lines A2780 and A2780cis were obtained from European Collection of Animal Culture (ECAC, Salisbury, UK). Cells were grown as monolayers in RPMI1640 medium with L-glutamine (GibcoBRL, Paisley, UK) supplemented with $10 \%$ fetal calf serum (GibcoBRL) and antibiotic/antimycotic solution $(100 \mathrm{U} / \mathrm{ml}$ of penicillin, $100 \mu \mathrm{g} / \mathrm{ml}$ of streptomycin and $0.25 \mu \mathrm{g} / \mathrm{ml}$ of amphotericin B; GibcoBRL) and were maintained under standard tissue culture conditions at $37^{\circ} \mathrm{C}$ and $5 \%$ humidified atmosphere of $\mathrm{CO} 2$. The acquired resistance of A2780cis cells was maintained by supplementation of media with $1 \mathrm{mM}$ of cisplatin (Sigma-Aldrich Co., St. Louis, MI, USA) every second passage. IC $_{50}$ concentra- tions of homobrassinin (K1; N-[2-(indol-3-yl)ethyl] -S-methyldithiocarbamate), thiazino[6,5-b]indol (K157; 2-(4'-fluorphenylamino)-4H-1,3-tiazino[6,5-b]indol) (Fig. 1) and cisplatin determined in our previous studies $^{11,8}$ on resistant A2780cis cells were applied in all assays.

\section{2. Flow Cytometric Analysis (FCM)}

Human ovarian adenocarcinoma cells A2780 and A2780cis $\left(1 \times 10^{6}\right)$ were seeded for FCM analyses in Petri dishes and treated with homobrassinin, thiazino[6,5-b]indol and cisplatin at $\mathrm{IC}_{50}$ concentrations for 24,48 or $72 \mathrm{~h}$ depending on experimental scheme. Floating and adherent cells were harvested, washed in PBS, divided for particular analysis and stained prior to analysis. Fluorescence was detected after 15-30 min incubation at room temperature in the dark using a BD FACSCalibur flow cytometer (Becton Dickinson, San Jose, CA, USA). A minimum of 1 $\times 10^{4}$ cells were analysed per analysis. All experiments were performed in triplicate.

\section{3. Apoptosis Detection Via Annexin V/PI Staining}

For apoptosis detection, floating and adherent A2780 and A2780cis cells $\left(1 \times 10^{6}\right)$ were harvested 24,48 and 72 $\mathrm{h}$ after homobrassinin, thiazino[6,5-b]indol and cisplatin treatment (IC50 concentrations). Complete cell population was washed in PBS and stained using annexin V Alexa Fluor ${ }^{\circledR} 647$ conjugate (Thermo Fisher, Waltham, MA, USA) for $15 \mathrm{~min}$ at room temperature in the dark followed by incubation with propidium iodide (PI; Sigma-Aldrich, Saint-Louis, MO, USA) and analysed by flow cytometer (BD FACSCalibur).

\section{4. Detection of Active Caspase 3}

Activation of executioner caspases (such as caspase 3) subsequently impacts the main structural proteins and activates other enzymes, leading to apoptosis. The changes in caspase 3 activation were analysed with FCM using active Caspase-3 PE Mab (Cell Signaling Technology, Danvers, MA, USA). The cells were harvested 24, 48 and $72 \mathrm{~h}$ after homobrassinin, thiazino[6,5-b]indol and cisplatin treatment ( $\mathrm{IC}_{50}$ concentrations). The cell population was stained with phycoerythrin (PE) conjugated antibody and incubated for $30 \mathrm{~min}$ at room temperature in the dark. The cells

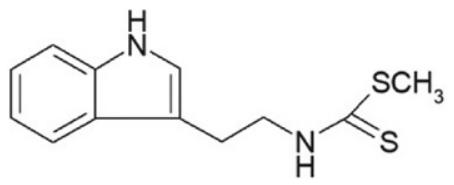

homobrassinin

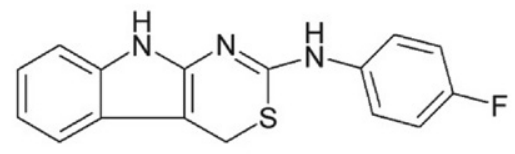

2-(4'-fluorphenylamino)-4H-1,3-tiazino[6,5-b]indole

Figure 1. Structure of homobrassinin (K1; N-[2-(indol-3-yl)ethyl]-S-methyldithiocarbamate) and thiazino[6,5-b]indol (K157; 2-(4' - fluorphenylamino)-4H-1,3-tiazino[6,5-b]indol). 
were then washed twice with PBS, resuspended in $500 \mu \mathrm{M}$ of the total volume, and analysed $\left(1 \times 10^{4}\right.$ cell per sample).

\section{5. Detection of Mitochondrial Apoptotic Pathway Associated Proteins}

Cytochrome c release, Smac/DIABLO accumulation and caspase- 9 activity were analysed with FCM using Cytochrome c antibody (6H2) FITC conjugate; Smac/Diablo Rabbit $\mathrm{mAb}+$ goat anti-rabbit IgG $(\mathrm{H}+\mathrm{L})$ secondary antibody Alexa Fluor 488 and cleaved Caspase- 9 (Asp315) rabbit $\mathrm{mAb} \mathrm{PE}$ conjugate. The A2780 and A2780cis cells were harvested 24,48 and $72 \mathrm{~h}$ after homobrassinin, thiazino[6,5-b]indol and cisplatin treatment (IC50 concentrations). Cell population was stained with conjugated antibody and incubated for $30 \mathrm{~min}$ at room temperature in the dark or stained with primary antibody (30 min), followed by secondary conjugated antibody staining $(15 \mathrm{~min}$ in dark). The cells were then washed with PBS, resuspended in $500 \mu \mathrm{L}$ of the total volume in PBS, and analysed $\left(1 \times 10^{4}\right.$ cells per sample) by a BD FACSCalibur flow cytometer.

\section{6. Western Blotting}

Western blot analysis were carried out according to the standard protocol. ${ }^{12}$ The protein sample was separated on $10 \%$ SDS-PAGE, electroblotted onto Immobilon-P transfer membrane (Millipore Co., Billerica, MA, USA) and incubated using primary antibodies shown below: anti-HSP40 (\#4868, 1:1000; Cell Signaling, Danvers, MA, USA), anti-protein disulfide isomerase (anti-HSP57; \#3501, 1:1000; Cell Signaling Technology, Danvers, MA, USA), anti- HSP60 (\#12165, 1:1000; Cell Signaling, Danvers, MA, USA), anti-HSP70 (\#4873, 1:1000; Cell Signaling Technology, Danvers, MA, USA), anti-HSP90 (\#4877, 1:1000; Cell Signaling Technology, Danvers, MA, USA)
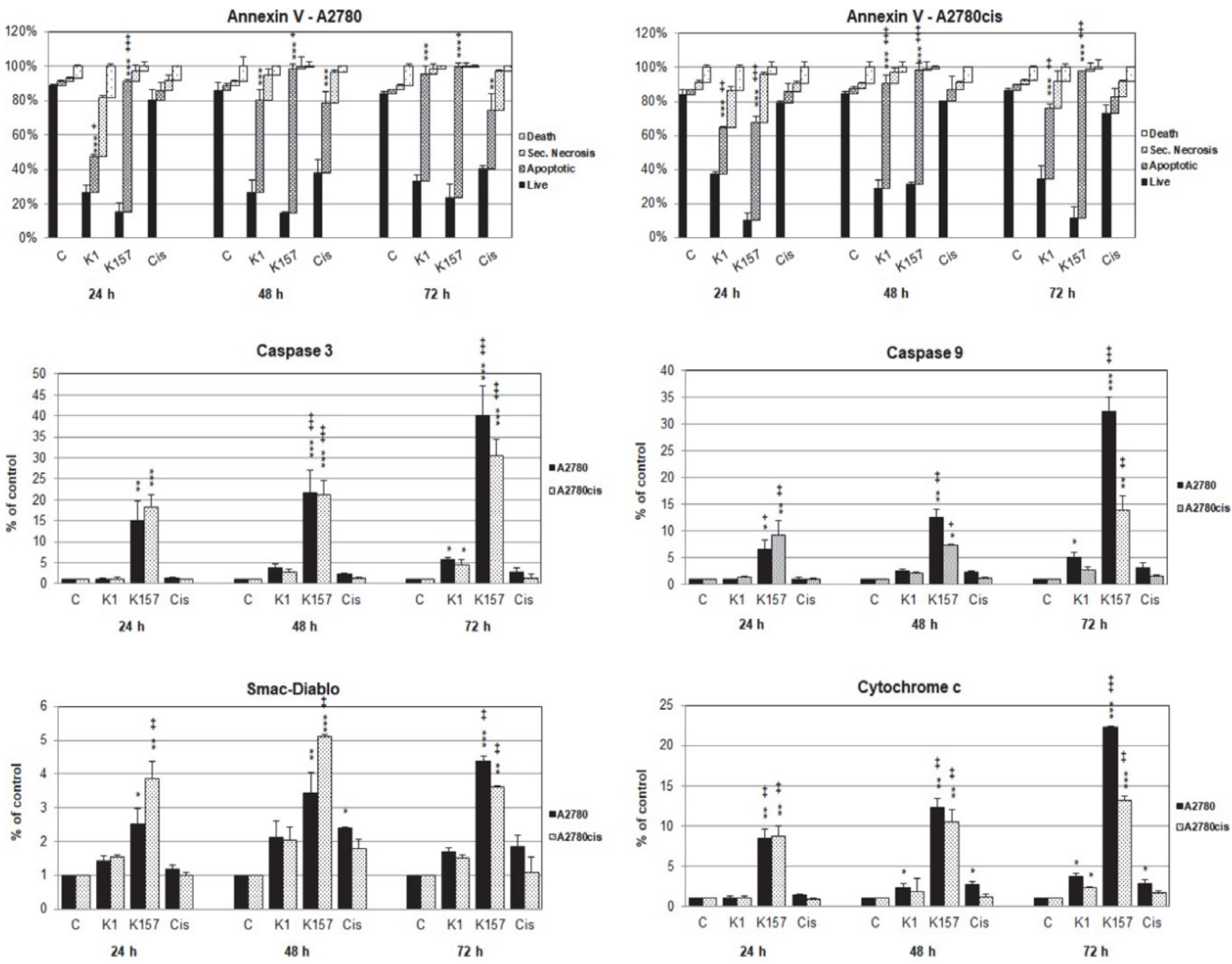

Figure 2. Effects of IC50 concentrations of homobrassinin (K1), thiazino[6,5-b]indol (K157), and cisplatin (Cis) on annexin V, caspase 3, caspase 9, smac-diablo, and cytochrome C in A2780 and A2780cis cell lines. The cells were grown in standard growth media for 24 h and then treated with mentioned above substances for 24,48 , and $72 \mathrm{~h}$ (untreated control $-\mathrm{C}$ ). ${ }^{\star} \mathrm{p}<0.05 ;{ }^{\star *} \mathrm{p}<0.01^{\star * *} \mathrm{p}<0.001 \mathrm{vs}$. C and $+\mathrm{p}<0.05 ;++\mathrm{p}<0.01 ;+++\mathrm{p}<0.001$ vs. Cis (three independent experiments) 
and anti- $\alpha$-tubulin (sc-5286, 1:200; Santa Cruz Biotechnology, Dallas, Texas, USA). Subsequently, the membranes were incubated with secondary horseradish peroxidase-conjugated antibodies (PI-31461, 1:10.000, goat anti-rabbit IgG $\mathrm{F}\left(\mathrm{AB}^{\prime}\right) 2$ or PI-31436, 1:10.000, goat anti-mouse IgG $\mathrm{F}\left(\mathrm{AB} \mathrm{B}^{\prime}\right) 2$; Thermo Fisher Scientific, Waltham, MA, USA) for $1 \mathrm{~h}$, and the antibody reactivity was visualized with ECL Western blotting substrate (PI-32106, Thermo Fisher Scientific) using Kodak Biomax films (\#1788207, Sigma-Aldrich Co.).

\section{7. Statistical Analysis}

Data were processed using scientific graphing and ORIGIN analysis software (OriginLab Co., Northampton, MA, USA) and statistically analysed using one-way ANOVA followed by Tukey's multiple comparison tests.

\section{Results and Discussion}

Both indoles induced strong apoptosis in A2780 and A2780cis cells at $24 \mathrm{~h}$ compared to cisplatin that showed a pro-apoptotic effect later (at 48 and $72 \mathrm{~h}$ ) but only in A2780, not A2780cis cells (Fig. 2). Annexin V increased in A2780 and A2780cis cells $24 \mathrm{~h}$ after the addition of both indoles (Fig. 2). In this regard, K157 induced more pronounced externalization of phosphatidylserine in A2780cis cells compared to parental ones at $72 \mathrm{~h}$ time point. Changes in other selected markers of apoptosis, such as caspase 3 and 9, smac-diablo, and cytochrome $\mathrm{C}$, confirmed the pro-apop- totic potential of both indoles tested, which was more pronounced in the case of K157 than in K1 (Fig. 2). Indeed, K157 increased both caspase 3 and 9 activities, increased the accumulation of smac-diablo, and induced the release of cytochrome $\mathrm{C}$ in both cell lines and at all time points monitored (Fig. 2). Interestingly, K157 increased smac-diablo accumulation in A2780cis cells at earlier time intervals (Fig. 2). On the other hand, cisplatin-induced the release of cytochrome C only in A2780 cells, not in A2780cis cells (Fig. 2). This effect of cisplatin correlated well with the mentioned externalization of phosphatidylserine (annexin V/PI staining) and apoptosis in A2780 cells (Fig. 2).

Moreover, indoles reduced the level of HSP40, protein disulfide isomerase (HSP57), HSP70, and HSP90 in A2780 cells irreversibly and HSP40 and HSP57 in A2780cis cells reversibly (Fig. 3A, B; Tab. 1A, B). In this regard, indole K1 downregulated HSP70 in both cell lines at $24 \mathrm{~h}$ and HSP40 and HSP90 in A2780 cells at $48 \mathrm{~h}$ (Fig. 3A, B; Tab. 1A, B). On the other hand, indole K157 downregulated HSP40 and HSP70 in both A2780 and A2780cis cells and HSP57 and HSP90 in A2780 cells at $24 \mathrm{~h}$ (Fig. 3A, B; Tab. 1A, B). Cisplatin did sufficiently modify the level of monitored HSPs in A2780 cells (Fig. 3A, B; Tab. 1A, B) and downregulated both HSP40 and HSP57 in A2780 cells reversibly at $48 \mathrm{~h}$ and $24 \mathrm{~h}$, respectively (Fig. 3A; Tab. 1A) and HSP57 in A2780cis cells at 48h (Fig. 3B; Tab. 1B). The level of only HSP60 did not change in A2780 or A2780cis cells after the indole or cisplatin administration (Fig. 3A, $\mathrm{B}$; Tab. 1A, B). In general, the reduction in the level of HSPs in A2780 cells compared to A2780cis cells was more significant (Fig. 3A, B; Tab. 1A, B).
A)

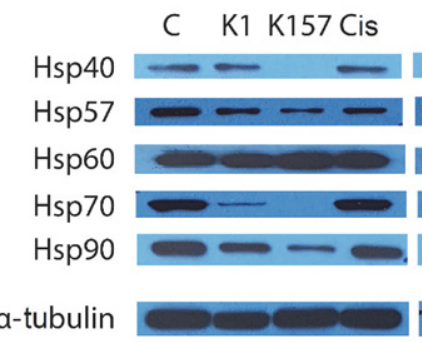

B)

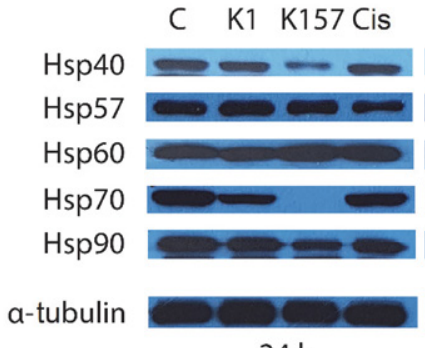

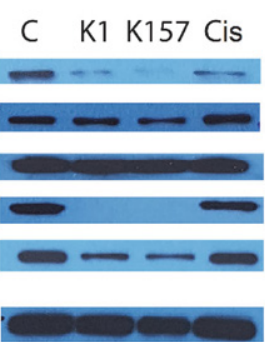

$48 \mathrm{~h}$

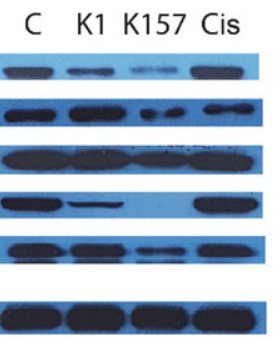

$48 \mathrm{~h}$

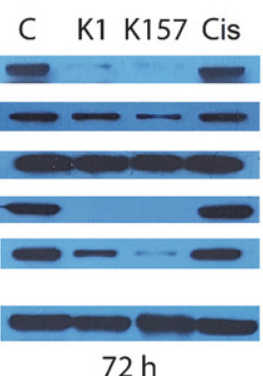

C $\mathrm{K} 1 \mathrm{~K} 157$ Cis

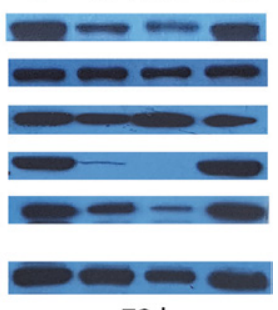

$72 \mathrm{~h}$

Figure 3. Effects of IC50 concentrations of homobrassinin (K1), thiazino[6,5-b]indol (K157), and cisplatin (Cis) on HSP40, HSP57 (PDI), HSP60, HSP70, and HSP90 in A2780 (A) and A2780cis (B) cell lines. The cells were grown in standard growth media for $24 \mathrm{~h}$ and then treated with the substances mentioned above for 24,48 , and $72 \mathrm{~h}$ (untreated control - C). The detection of $\alpha$-tubulin confirmed equal loading. A representative image of three independent experiments is shown. 
Table I. Effects of IC50 concentrations of homobrassinin (K1), thiazino[6,5-b]indol (K157), and cisplatin (Cis) on HSP40, HSP57 (PDI), HSP60, HSP70, and HSP90 in A2780 (A) and A2780cis (B) cell lines. Ratios \pm standard deviation from quantitative densitometric analysis of HSP40, HSP57, HSP60, HSP70, and HSP90 were normalized to a-tubulin. Ratios at untreated control (C) were arbitrarily set to $1 .{ }^{*} \mathrm{p}<0.05 ;{ }^{* *} \mathrm{p}<0.01 \mathrm{vs}$. $\mathrm{C}$ (three independent experiments; one-way ANOVA tests).

\begin{tabular}{|c|c|c|c|c|c|c|}
\hline $\mathbf{A}$ & & Hsp40 & Hsp57 & Hsp60 & Hsp70 & Hsp90 \\
\hline \multirow{5}{*}{$24 \mathrm{~h}$} & $\mathrm{C}$ & $1.0 \pm 0.1$ & $1.0 \pm 0.1$ & $1.0 \pm 0.2$ & $1.0 \pm 0.1$ & $1.0 \pm 0.1$ \\
\hline & K1 & $1.3 \pm 0.3$ & $0.7 \pm 0.3$ & $1.3 \pm 0.2$ & $0.1 \pm 0.1^{* *}$ & $0.7 \pm 0.3$ \\
\hline & K157 & $0.0 \pm 0.1^{\star *}$ & $0.3 \pm 0.1^{\star}$ & $1.3 \pm 0.3$ & $0.0 \pm 0.1^{\star *}$ & $0.1 \pm 0.1^{* *}$ \\
\hline & Cis & $1.6 \pm 0.3$ & $0.5 \pm 0.1^{\star}$ & $1.1 \pm 0.1$ & $0.8 \pm 0.3$ & $0.7 \pm 0.3$ \\
\hline & & Hsp40 & Hsp57 & Hsp60 & Hsp70 & Hsp90 \\
\hline \multirow{5}{*}{$48 \mathrm{~h}$} & $\mathrm{C}$ & $1.0 \pm 0.1$ & $1.0 \pm 0.2$ & $1.0 \pm 0.3$ & $1.0 \pm 0.2$ & $1.0 \pm 0.1$ \\
\hline & K1 & $0.0 \pm 0.1^{\star *}$ & $1.0 \pm 0.3$ & $1.1 \pm 0.2$ & $0.0 \pm 0.1^{\star *}$ & $0.0 \pm 0.1^{* *}$ \\
\hline & K157 & $0.0 \pm 0.2^{* *}$ & $0.9 \pm 0.1$ & $1.3 \pm 0.2$ & $0.5 \pm 0.1^{\star}$ & $0.3 \pm 0.1^{\star}$ \\
\hline & Cis & $0.1 \pm 0.1^{\star *}$ & $1.2 \pm 0.3$ & $1.0 \pm 0.3$ & $0.7 \pm 0.3$ & $1.1 \pm 0.3$ \\
\hline & & Hsp40 & Hsp57 & Hsp60 & Hsp70 & Hsp90 \\
\hline \multirow{4}{*}{$72 \mathrm{~h}$} & $\mathrm{C}$ & $1.0 \pm 0.1$ & $1.0 \pm 0.1$ & $1.0 \pm 0.2$ & $1.0 \pm 0.2$ & $1.0 \pm 0.1$ \\
\hline & K1 & $0.0 \pm 0.1^{* *}$ & $0.9 \pm 0.2$ & $1.1 \pm 0.3$ & $0.0 \pm 0.1^{* *}$ & $0.5 \pm 0.1^{\star}$ \\
\hline & K157 & $0.0 \pm 0.2^{\star *}$ & $0.4 \pm 0.1^{\star}$ & $0.8 \pm 0.2$ & $0.0 \pm 0.1^{\star *}$ & $0.0 \pm 0.1^{\star *}$ \\
\hline & Cis & $1.1 \pm 0.1$ & $0.8 \pm 0.3$ & $0.9 \pm 0.2$ & $1.1 \pm 0.3$ & $0.9 \pm 0.3$ \\
\hline B & & Hsp40 & Hsp57 & Hsp60 & Hsp70 & Hsp90 \\
\hline \multirow{5}{*}{$24 \mathrm{~h}$} & $\mathrm{C}$ & $1.0 \pm 0.1$ & $1.0 \pm 0.2$ & $1.0 \pm 0.2$ & $1.0 \pm 0.1$ & $1.0 \pm 0.2$ \\
\hline & K1 & $0.8 \pm 0.2$ & $1.1 \pm 0.3$ & $0.9 \pm 0.2$ & $0.6 \pm 0.3$ & $0.8 \pm 0.2$ \\
\hline & K157 & $0.5 \pm 0.1^{*}$ & $1.1 \pm 0.2$ & $1.3 \pm 0.3$ & $0.0 \pm 0.1^{* *}$ & $0.7 \pm 0.2$ \\
\hline & Cis & $0.8 \pm 0.3$ & $0.7 \pm 0.2$ & $1.2 \pm 0.2$ & $0.7 \pm 0.2$ & $0.7 \pm 0.2$ \\
\hline & & Hsp40 & Hsp57 & Hsp60 & Hsp70 & Hsp90 \\
\hline \multirow{5}{*}{$48 \mathrm{~h}$} & $\mathrm{C}$ & $1.0 \pm 0.1$ & $1.0 \pm 0.2$ & $1.0 \pm 0.2$ & $1.0 \pm 0.1$ & $1.0 \pm 0.1$ \\
\hline & $\mathrm{K} 1$ & $0.6 \pm 0.2$ & $1.3 \pm 0.3$ & $1.0 \pm 0.3$ & $0.4 \pm 0.1^{\star}$ & $1.0 \pm 0.2$ \\
\hline & K157 & $0.4 \pm 0.1^{\star}$ & $0.6 \pm 0.2$ & $0.8 \pm 0.2$ & $0.0 \pm 0.1^{* *}$ & $0.5 \pm 0.1^{\star}$ \\
\hline & Cis & $1.3 \pm 0.3$ & $0.7 \pm 0.2$ & $1.0 \pm 0.3$ & $1.0 \pm 0.2$ & $0.9 \pm 0.2$ \\
\hline & & Hsp40 & Hsp57 & Hsp60 & Hsp70 & Hsp90 \\
\hline \multirow{4}{*}{$72 \mathrm{~h}$} & $\mathrm{C}$ & $1.0 \pm 0.2$ & $1.0 \pm 0.3$ & $1.0 \pm 0.2$ & $1.0 \pm 0.1$ & $1.0 \pm 0.1$ \\
\hline & $\mathrm{K} 1$ & $1.0 \pm 0.3$ & $1.0 \pm 0.3$ & $1.0 \pm 0.3$ & $0.0 \pm 0.1^{* *}$ & $0.8 \pm 0.2$ \\
\hline & K157 & $1.0 \pm 0.2$ & $1.4 \pm 0.3$ & $1.8 \pm 0.4$ & $0.1 \pm 0.1^{* *}$ & $0.4 \pm 0.1^{*}$ \\
\hline & Cis & $1.0 \pm 0.1$ & $1.0 \pm 0.2$ & $0.7 \pm 0.2$ & $1.4 \pm 0.2$ & $1.1 \pm 0.3$ \\
\hline
\end{tabular}

Homobrassinin (K1) had the most pronounced antiproliferative activity of the seven tested brassinin derivatives. ${ }^{13}$ This compound accumulated human colorectal adenocarcinoma Caco2 cells in the G2/M phase of the cell cycle and inhibited microtubule formation through the dysregulation of $\alpha$-tubulin, $\alpha$ 1-tubulin, and $\beta 5$-tubulin expression. ${ }^{13}$ Moreover, the apoptosis of $\mathrm{Caco} 2$ cells induced by K1 was associated with DNA fragmentation, loss of mitochondrial membrane potential, and intracellular reactive oxygen species production..$^{13}$ Our results demonstrated that $\mathrm{K} 1$ induced the apoptosis of cisplatin-sensitive human ovarian adenocarcinoma A2780 cells and cisplatin-resistant derivative A2780cis cells, both associated with annexin V/PI positivity, increased caspase 3 activity, and released cytochrome C. K157 showed even more pronounced apoptosis-stimulating effect compared to K1, with increased annexin V/PI positivity, caspase 3 and 9 activities, the accumulation of smac-diablo, and the release of cytochrome $\mathrm{C}$ in both cisplatin-sensitive as well as cisplatin-resistant cells in a time-dependent manner. The K157-induced apoptosis of A2780cis cells has already been confirmed by a lower concentration than $\mathrm{IC}_{50}$ and through the detection of increased pro-apoptotic Bad protein. ${ }^{8} \mathrm{Cis}-$ platin increased the release of cytochrome $\mathrm{C}$ and the externalization of phosphatidylserine but only in the sensitive A2780 cells, not in the resistant ones.

Hsp90 is one of the most abundant molecular chaperones and highly conserved proteins, the association of which is required for the stability and function of multiple mutated, chimeric, and overexpressed signaling proteins that promote the growth and/or survival of cancer cells. ${ }^{14}$ Interestingly, antiproliferative and pro-apoptotic effects of 
K157 were potentiated by HSP90 inhibitor 17-DMAG in A2780cis cells, which suggests a new strategy in cancer resistance therapy. ${ }^{8}$ Similarly, combined exposure of A2780cis cells to HSP90 inhibitor geldanamycin and cisplatin yielded greater than the additive cytotoxic effect. ${ }^{11}$ We have already shown that cisplatin-resistant CP70 and C200 cells (derivatives of parental A2780 cells) revealed significantly higher expression of HSPCA (HSP90a) and TRA1 (GRP94) proteins. ${ }^{15}$ Overexpressed GRP94 and HSP90 a might protect CP70 and C200 cells from cisplatin toxicity and render them more resistant. ${ }^{15}$ Indeed, the role of HSPs in cisplatin resistance has been demonstrated in a previous study, ${ }^{16}$ where HSP27, mtHSP75, and HSP70 were upregulated in the cisplatin-resistant ovarian tumor cell line $2008 / \mathrm{C} 13^{\star} 5.25$ in contrast to the sensitive 2008 one. Therefore, in the present study, we decided to test the effect of indoles on the level of selected HSPs, which can have significant cytoprotective effects in pathological conditions through the initiation of protein folding, repair, refolding of misfolded peptides, and possible degradation of irreparable proteins. ${ }^{17}$ Although some HSPs are produced constitutively, most are molecular chaperones that are normally overexpressed by cells in response to inducible signals that may lead to protein denaturation. ${ }^{18}$ HSPs appear to have a large number of functions in apoptosis itself, which, in most cases, leads to suppression of apoptotic pathways. ${ }^{17}$ In our case, the apoptosis-stimulating effects of indoles were associated with an irreversible decrease in HSP90 and HSP70 in both A2780 as well as A2780cis cells. At the same time, cisplatin did not cause any change in HSP90 and HSP70.

Moreover, Beere et al. ${ }^{19}$ demonstrated that Hsp70, together with its co-chaperone Hsp40, inhibits nitric oxide-induced apoptosis in ATPase- and chaperoning-dependent manner by blocking the mitochondrial translocation of Bax, a pro-apoptotic member of the Bcl-2 family. ${ }^{19}$ HSP70 and HSP40 were irreversibly downregulated as a result of the effect of both K1 and K157 indoles on A2780 and A2780cis cells. On the other hand, HSP40 protein was reversibly downregulated as a result of cisplatin in A2780 cells. Indeed, downregulation of HSP70 and/or HSP40 correlated well with the apoptosis induced by either indole in both cell lines or cisplatin in A2780 cells. Despite all the negative functions of HSPs in attenuating apoptosis, Hsp60, found in mitochondria complexed with Hsp10, is involved in a signaling complex that leads to pro-caspase-3 activation and cytochrome-dependent apoptosis. In addition, several studies have shown that cytosolic Hsp60 is associated with the pro-apoptotic protein Bax, leading to its activation as well as to apoptosis mediated by this protein. $^{20,21}$ Indeed, neither indoles nor cisplatin caused a change in the level of HSP60 protein, and they are unlikely to be related to the process of apoptosis induced by indoles or cisplatin in A2780 or A2780cis cells.

HSP57 (PDI) protein is highly expressed in many tumor cell types, including melanoma, prostate, lung, renal, brain, male germ cell tumors, and ovarian. ${ }^{22}$ Conversely, decreased PDI levels are also associated with higher survival rates in patients with breast cancer and glioblastoma. ${ }^{23}$ Although PDI promotes cancer cell survival, its silencing causes greater cytotoxicity in human breast cancer and neuroblastoma cell lines due to caspase activation. ${ }^{24}$ The suppression of apoptosis by PDI itself serves a mechanism to promote tumor growth and metastasis. In this regard, K157 induced both irreversible and reversible downregulation of HSP57 in A2780 and A2780cis cells, respectively, while cisplatin caused a reversible decrease in HSP57 in both cell lines monitored.

\section{Conclusions}

Our results signify more pronounced sensitizing and/or proapoptotic potential of thiazino[6,5-b]indol compared to homobrassinin accompanied by increased smac-diablo accumulation at earlier time intervals and pronounced externalization of phosphatidylserine at $72 \mathrm{~h}$ in A2780cis compared to A2780 cells. The apoptosis-stimulating effect of thiazino[6,5-b]indol in A2780cis cells was associated with significant irreversible downregulation of HSP70 and HSP90 and partly with a decrease of HSP40. On the other hand, cisplatin induced the apoptosis of sensitive A2780 cells with reversible downregulation of HSP40 and HSP57. In conclusion, the effect of thiazino[6,5-b]indol on resistant A2780cis cells could have a great utility in both the potential prevention and the treatment of other cisplatin-resistant tumor cells.

\section{Conflict of Interest}

There is no conflict of interest.

\section{Acknowledgments}

This study was supported (50\%) by the project Medicínsky univerzitný park $\mathrm{v}$ Košiciach (MediPark, Košice) ITMS: 26220220185 (95\%) supported by Operational Programme Research and Development (OPVaV2012/2.2/08-RO) (Contract No. OPVaV/12/2013). We would like to thank also the Slovak Grant Agency for Science (Grant No. 1/0536/19) for financial support of this work. The authors are grateful to Mgr. Marián Čurda for drawing the chemical structures of indoles.

\section{References}

1. Thomsen, L. H.; Schnack, T. H.; Buchardi, K.; Hummelshoj, L.; Missmer, S. A.; Forman, A.; Blaakaer, J., Risk factors of epithelial ovarian carcinomas among women with endometriosis: a systematic review. Acta Obstet Gynecol Scand 2017, 96 (6), 761-778. DOI:10.1111/aogs.13010 
2. Luvero, D.; Milani, A.; Ledermann, J. A., Treatment options in recurrent ovarian cancer: latest evidence and clinical potential. Ther Adv Med Oncol 2014, 6 (5), 229-39.

DOI:10.1177/1758834014544121

3. Sharma, R.; Graham, J.; Mitchell, H.; Brooks, A.; Blagden, S.; Gabra, H., Extended weekly dose- dense paclitaxel/carboplatin is feasible and active in heavily pre-treated platinum-resistant recurrent ovarian cancer. Br J Cancer 2009, 100 (5), 707-12. DOI:10.1038/sj.bjc.6604914

4. Rose, P. G.; Mossbruger, K.; Fusco, N.; Smrekar, M.; Eaton, S.; Rodriguez, M., Gemcitabine reverses cisplatin resistance: demonstration of activity in platinum- and multidrug-resistant ovarian and peritoneal carcinoma. Gynecol Oncol 2003, 88 (1), 17-21. DOI:10.1006/gyno.2002.6850

5. Katsumata, N.; Yasuda, M.; Isonishi, S.; Takahashi, F.; Michimae, H.; Kimura, E.; Aoki, D.; Jobo, T.; Kodama, S.; Terauchi, F.; Sugiyama, T.; Ochiai, K.; Japanese Gynecologic Oncology, G., Long-term results of dose-dense paclitaxel and carboplatin versus conventional paclitaxel and carboplatin for treatment of advanced epithelial ovarian, fallopian tube, or primary peritoneal cancer (JGOG 3016): a randomised, controlled, open-label trial. Lancet Oncol 2013, 14 (10), 1020-6.

DOI:10.1016/S1470-2045(13)70363-2

6. Garcia, A. A.; Hirte, H.; Fleming, G.; Yang, D.; Tsao-Wei, D. D.; Roman, L.; Groshen, S.; Swenson, S.; Markland, F.; Gandara, D.; Scudder, S.; Morgan, R.; Chen, H.; Lenz, H. J.; Oza, A. M., Phase II clinical trial of bevacizumab and low-dose metronomic oral cyclophosphamide in recurrent ovarian cancer: a trial of the California, Chicago, and Princess Margaret Hospital phase II consortia. J Clin Oncol 2008, 26 (1), 76-82.

DOI:10.1200/JCO.2007.12.1939

7. Gotlieb, W. H.; Amant, F.; Advani, S.; Goswami, C.; Hirte, H.; Provencher, D.; Somani, N.; Yamada, S. D.; Tamby, J. F.; Vergote, I., Intravenous aflibercept for treatment of recurrent symptomatic malignant ascites in patients with advanced ovarian cancer: a phase 2, randomised, double-blind, placebo-controlled study. Lancet Oncol 2012, 13 (2), 154-62. DOI:10.1016/S1470-2045(11)70338-2

8. Solarova, Z.; Kello, M.; Varinska, L.; Budovska, M.; Solar, P., Inhibition of heat shock protein (Hsp) 90 potentiates the antiproliferative and pro-apoptotic effects of 2-(4'fluoro-phenylamino)-4H- 1,3-thiazine[6,5-b]indole in A2780cis cells. Biomed Pharmacother 2017, 85, 463-471.

DOI:10.1016/j.biopha.2016.11.052

9. Banerjee Mustafi, S.; Chakraborty, P. K.; Raha, S., Modulation of Akt and ERK1/2 pathways by resveratrol in chronic myelogenous leukemia (CML) cells results in the downregulation of Hsp70. PLoS One 2010, 5 (1), e8719.

DOI:10.1371/journal.pone.0008719
10. Pilatova, M.; Sarissky, M.; Kutschy, P.; Mirossay, A.; Mezencev, R.; Curillova, Z.; Suchy, M.; Monde, K.; Mirossay, L.; Mojzis, J., Cruciferous phytoalexins: antiproliferative effects in T-Jurkat leukemic cells. Leuk Res 2005, 29 (4), 415-21.

DOI:10.1016/j.leukres.2004.09.003

11. Solar, P.; Horvath, V.; Kleban, J.; Koval, J.; Solarova, Z.; Kozubik, A.; Fedorocko, P., Hsp90 inhibitor geldanamycin increases the sensitivity of resistant ovarian adenocarcinoma cell line A2780cis to cisplatin. Neoplasma 2007, 54 (2), 127-30.

12. Mahmood, T.; Yang, P. C., Western blot: technique, theory, and trouble shooting. N Am J Med Sci 2012, 4 (9), 429-34.

DOI:10.4103/1947-2714.100998

13. Kello, M.; Drutovic, D.; Chripkova, M.; Pilatova, M.; Budovska, M.; Kulikova, L.; Urdzik, P.; Mojzis, J., ROS-dependent antiproliferative effect of brassinin derivative homobrassinin in human colorectal cancer Caco 2 cells. Molecules 2014, 19 (8), 10877-97. DOI:10.3390/molecules190810877

14. Neckers, L., Hsp90 inhibitors as novel cancer chemotherapeutic agents. Trends Mol Med 2002, 8 (4 Suppl), S55-61. DOI:10.1016/S1471-4914(02)02316-X

15. Solar, P.; Sytkowski, A. J., Differentially expressed genes associated with cisplatin resistance in human ovarian adenocarcinoma cell line A2780. Cancer Lett 2011, 309 (1), 11-8. DOI:10.1016/j.canlet.2011.05.008

16. Yamamoto, K.; Okamoto, A.; Isonishi, S.; Ochiai, K.; Ohtake, Y., Heat shock protein 27 was up- regulated in cisplatin resistant human ovarian tumor cell line and associated with the cisplatin resistance. Cancer Lett 2001, 168 (2), 173-81. DOI:10.1016/S0304-3835(01)00532-8

17. Ikwegbue, P. C.; Masamba, P.; Oyinloye, B. E.; Kappo, A. P., Roles of Heat Shock Proteins in Apoptosis, Oxidative Stress, Human Inflammatory Diseases, and Cancer. Pharmaceuticals (Basel) 2017, 11 (1). DOI:10.3390/ph11010002

18. Srivastava, P., Roles of heat-shock proteins in innate and adaptive immunity. Nat Rev Immunol 2002, 2 (3), 185-94.

19. Beere, H. M., "The stress of dying": the role of heat shock proteins in the regulation of apoptosis. J Cell Sci 2004, $117(\mathrm{Pt}$ 13), 2641-51. DOI:10.1242/jcs.01284

20. Samali, A.; Cai, J.; Zhivotovsky, B.; Jones, D. P.; Orrenius, S., Presence of a pre-apoptotic complex of pro-caspase-3, Hsp60 and Hsp10 in the mitochondrial fraction of jurkat cells. EMBO J 1999, 18 (8), 2040-8. DOI:10.1093/emboj/18.8.2040

21. Gupta, S.; Knowlton, A. A., Cytosolic heat shock protein 60 , hypoxia, and apoptosis. Circulation 2002, 106 (21), 2727-33.

22. Xu, S.; Sankar, S.; Neamati, N., Protein disulfide isomerase: a promising target for cancer therapy. Drug Discov Today 2014, 19 (3), 222-40. DOI:10.1016/j.drudis.2013.10.017ww 


\section{Povzetek}

Fitoaleksini so snovi s protimikrobnimi lastnostmi, ki jih rastline proizvajajo po napadu mikroorganizmov, zlasti fitopatogenih gliv in virusov. Trenutno jih preučujejo tudi zaradi njihovih protitumorskih učinkov. Naš cilj je bil proučiti apoptozo-stimulirajoče delovanje homobrassinina and thiazino[6,5-b]indola v celicah človeškega ovarijskega adenokarcinoma A2780 and A2780cis s pomočjo pretočne citometrične analize aneksina V/PI, aktivnosti kaspaz 3 in 9, sproščanja citokroma C in kopičenja smac-diablo. S tehniko prenosa po westernu smo spremljali tudi učinek obeh indolov na odziv proteinov toplotnega šoka $\mathrm{v}$ teh celicah. Thiazino [6,5-b]indol je $\mathrm{v}$ primerjavi s homobrassininom pokazal izrazitejši senzibilizacijski in/ali proapoptotični učinek, ki ga je spremljalo povečano kopičenje smac-diabla v zgodnejših časovnih intervalih in izrazita eksternalizacija fosfatidilserina po 72 urah v A2780cis celicah v primerjavi s celicami A2780. Učinek tiazino [6,5-b] indola, ki je stimuliral apoptozo, je bil v celicah A2780cis povezan z značilnim nepovratnim zmanjšanem HSP70 in HSP90, ter deloma $\mathrm{z}$ zmanjšanjem HSP40. Po drugi strani pa je cisplatin povzročil apoptozo občutljivih celic A2780 z reverzibilnim zmanjšanjem HSP40 in HSP57. Skratka, učinek tiazino [6,5-b]indola na odporne celice A2780cis bi bil lahko zelo koristen pri potencialnem preprečevanju in zdravljenju drugih tumorskih celic, odpornih na cisplatin.

Except when otherwise noted, articles in this journal are published under the terms and conditions of the Creative Commons Attribution 4.0 International License 